\title{
A Norleucine-resistant Mutant of Salmonella typhimurium with a Possible Defect in Valine Uptake or Regulation
}

\author{
By ANN C. HOBSON \\ Department of Genetics, University of Birmingham, Birmingham BI5 $2 T T$
}

(Received I 8 December 1973)

\section{INTRODUCTION}

All the Salmonella typhimurium mutants resistant to the methionine analogue norleucine described so far are also resistant to the analogues ethionine and $\alpha$-methylmethionine. They can be classed either as $m e t A(\mathrm{fbr})$ mutants with a homoserine- $O$-transsuccinylase, the first enzyme specific to methionine biosynthesis, resistant to feedback inhibition by methionine or $\alpha$-methylmethionine, or as met $K$ mutants with defects in $S$-adenosylmethionine (SAM) synthetase leading to abnormalities in methionine repression control (Lawrence, Smith \& Rowbury, 1968; Chater \& Rowbury, 1970; Hobson \& Smith, 1973). A recently isolated norleucine-resistant mutant of a cysteine and thymine auxotroph, cys $J_{538}$ thy $A$, was found to be sensitive to ethionine. This mutant, provisionally designated cys $J_{53} 8$ thy $A$ Nol-r, was studied in the hope that it might be a new type of methionine regulatory mutant.

\section{METHODS}

Organisms. All bacterial strains were derivatives of Salmonella typhimurium LT-2. CysJ538 thy $A$ Nol-r, a spontaneous norleucine-resistant mutant of cysJ538 thy $A$, was provided by Dr M. C. Jones-Mortimer, Department of Biochemistry, University of Leicester, as were strains carrying Escherichia coli $\mathrm{F}^{\prime}$-factors. Hfr strains were obtained from Dr K. E. Sanderson, Department of Biology, University of Calgary, Alberta, Canada. Phage L4, a non-lysogenizing variant of P22 (Smith \& Levine, 1967), was routinely used in transduction. Maintenance of stock cultures, growth of bacteria for genetical experiments, and the propagation, assay and maintenance of transducing phage were as described by Smith (I96I).

Media. Oxoid nutrient agar (NA) and broth (NB) were used. The minimal medium (MM) and minimal agar (MA) were those of Smith (196r) and were supplemented as required with the following $(\mu \mathrm{g} / \mathrm{ml})$ : DL-ethionine, 1000; $\alpha$-methyl-DL-methionine, I000; DL-norleucine, I000; thymine, 60; L-valine, 40; other amino acids, 20.

Genetical techniques. (i) Transduction. The technique of Smith (196I) was used. (ii) Conjugation. Overnight NB cultures of recipient and donor strains were mixed in the ratio I : I and the mixtures incubated without shaking for $30 \mathrm{~min}$. Dilutions $\left(\mathrm{IO}^{-2}\right)$ were then made in NB with gentle mixing and $0.2 \mathrm{ml}$ portions of these spread on to appropriately supplemented MA plates. Identical plates were spread with recipient and donor strains separately as controls. All plates were incubated for 40 to $48 \mathrm{~h}$. (iii) Episome transfer. Both transfer and curing of episomes were as described by Hobson \& Smith (1973).

Enzyme assays. Bacteria were cultured, extracts prepared and SAM synthetase activity assayed as described by Hobson \& Smith (1973). The $N^{5} N^{10}$-methylenetetrahydrofolate reductase assay was that used by Whitehouse \& Smith (1973). 

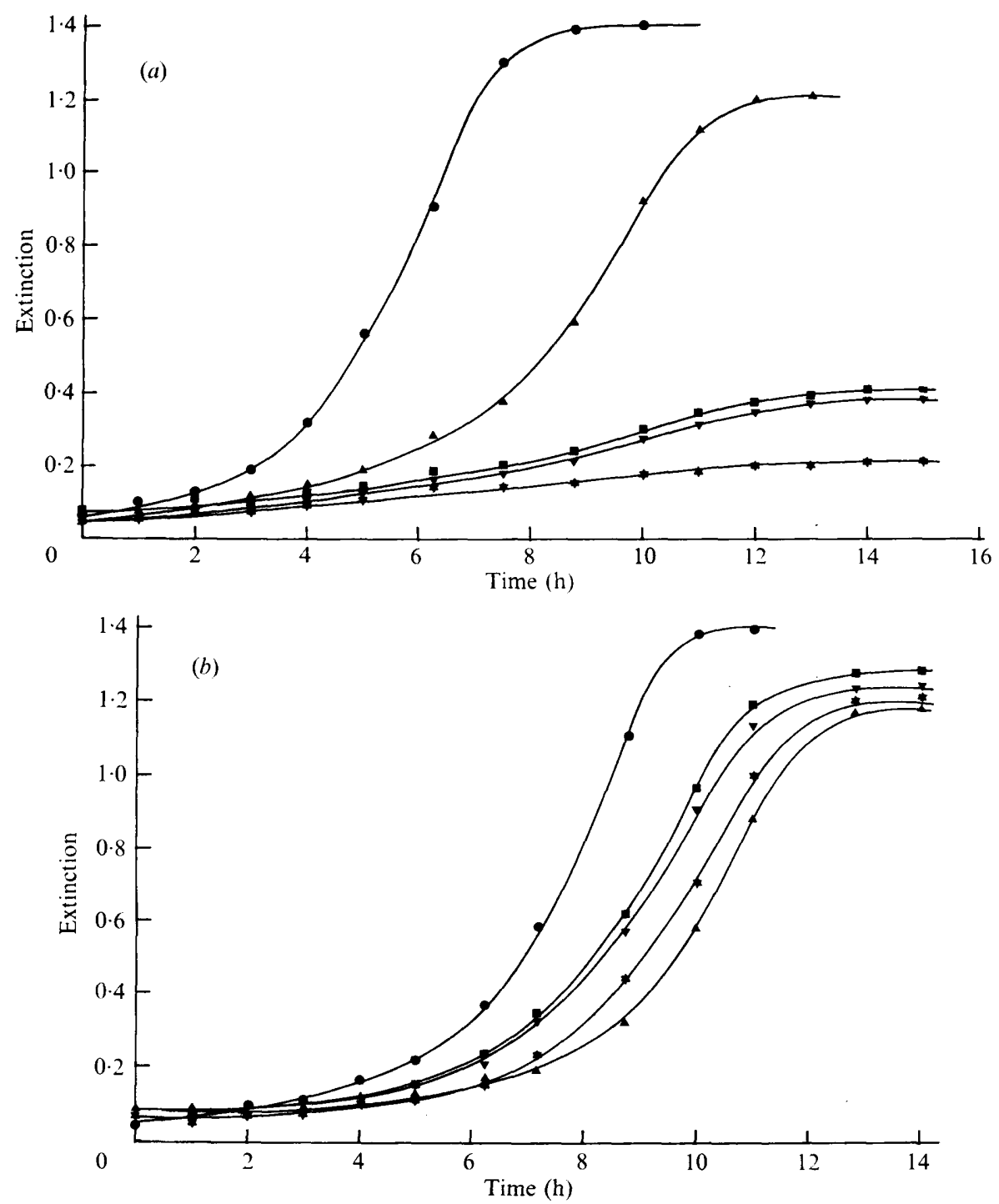

Fig. I. The effect of methionine, valine and leucine on growth in $\mathrm{MM}$ + norleucine of $(a)$ wild type;

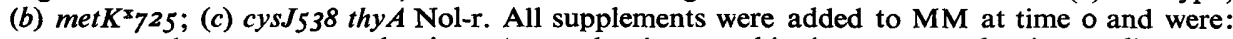

$\boldsymbol{\bullet}$, no supplement; $*$, norleucine; $\boldsymbol{\Delta}$, norleucine + methionine; $\boldsymbol{\nabla}$, norleucine+valine; $\boldsymbol{\square}$, norleucine + leucine. In addition, cysteine and thymine were added to cys $J_{53} 8$ thy $A$ Nol-r cultures.

Growth experiments. Bacterial cultures were grown to stationary phase in appropriately supplemented MM, concentrated tenfold and diluted into I $5 \mathrm{ml}$ fresh MM supplemented as required to give an extinction of 0.05 to 0.1 measured with a Unicam SP500 spectrophotometer $(650 \mathrm{~nm}, \mathrm{I} \mathrm{cm}$ light path). These cultures were incubated in $25 \mathrm{ml}$ conical flasks on a reciprocating shaker at $37^{\circ} \mathrm{C}$. Samples $(\mathrm{I} \cdot 5 \mathrm{ml})$ were removed at approximately hourly intervals, their extinction measured as before and the samples discarded. 


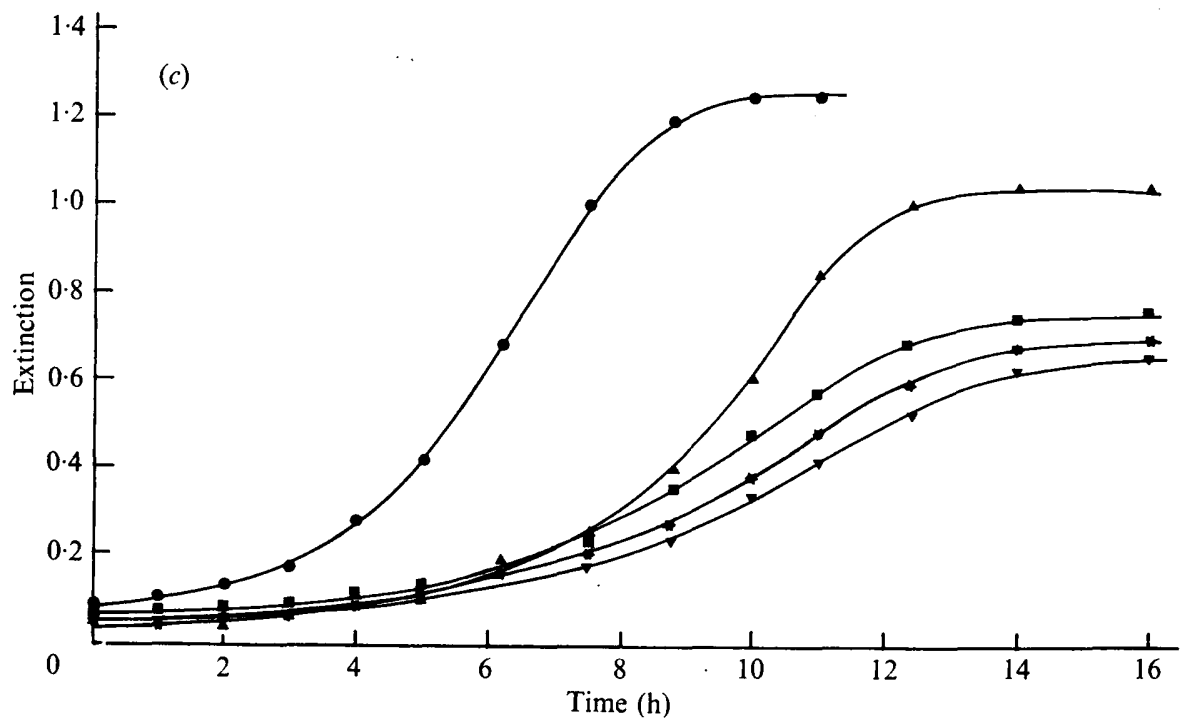

Fig. I (c). For legend see opposite.

\section{RESULTS AND DISCUSSION}

The norleucine resistance and ethionine sensitivity of cysJ 538 thy A Nol-r was first confirmed by growth experiments in liquid medium. The mutant was similarly shown to be sensitive to $\alpha$-methylmethionine so that the Nol-r mutation is unlikely to be of the met $A$ (f $\mathrm{br}$ ) type or to affect the methionine-specific permease because mutants of the permease are resistant to this analogue (Ayling \& Bridgeland, 1972). It was possible that the mutation was in either the met $J$ or met $K$ gene, both of which are involved in repression by methionine of its own synthesis, but gave a different analogue resistance pattern from previously studied mutations in these genes. Met $J$ is about 95 and $45 \%$ cotransducible with the metB and $m e t F$ structural genes respectively, and $m e t K$ is about $\mathrm{r} \%$ cotransducible with ser $A$ (Lawrence et al. 1968). However, in transduction crosses using cys $J 538$ thy $A$ Nol-r as donor no linkage of Nol-r with any of these auxotrophic markers could be detected out of at least 300 transductants tested in crosses with $m e t B$ and $m e t F$ as recipients and at least 1000 transductants with ser $A$ as recipient, showing that Nol-r is not in either the met $J$ or met $K$ gene. CysJ 538 thy A Nol-r had the same SAM synthetase activity as wild-type and so cannot be defective in some subunit or cofactor of the met $K$ enzyme.

In seeking a defect in methionine regulation, $c_{5} J_{538}$ thy $A$ Nol-r was shown not to excrete methionine in cross-feeding tests with a methionine auxotroph on supplemented MA (as in Lawrence et al. 1968) but other mutants do not excrete methionine and yet have elevated levels of methionine biosynthetic enzymes and methionine pools (Hobson, 1973). However, the cysJ 538 thy $A$ Nol-r $N^{5} N^{10}$-methylenetrahydrofolate reductase (involved in the terminal step of methonine biosynthesis) was found to be neither derepressed nor resistant to repression by $10 \mathrm{mM}$-L-methionine, and its methionine pool was the same as that of wild type as determined by a method involving a bioassay of methionine in cell extracts (Hobson, I973). Thus this Nol-r mutation, unlike all others which lead to norleucine resistance, does not affect methionine regulation.

Another explanation for the Nol-r phenotype could be interference with uptake of norleucine. This analogue is transported at low efficiency by the methionine permease (Ayling \& 
Bridgeland, 1972) and norleucine, leucine and isoleucine compete with valine for uptake by Escherichia coli, suggesting common uptake systems for these compounds (Cohen \& Rickenberg, I956). In addition, if part of the inhibition of wild type by norleucine results from interference with synthesis or utilization of another amino acid besides methionine, the Nol-r mutation could cause overproduction of the relevant amino acid. For example, Trupin, Dickerman, Nirenberg \& Weissbach (I966) showed that norleucine could be activated by tRNA ${ }^{\text {Leu }}$.

To test these hypotheses, the reversal of norleucine inhibition of wild-type growth by growth concentrations of methionine, valine and leucine was tested in MM. All three amino acids stimulated growth, methionine having the largest effect, their combined effects almost completely reversing the inhibition (Fig. I $a$ ). Thus norleucine must interfere with either uptake, synthesis or utilization of all three compounds. As expected, methionine did not stimulate growth of met $K^{\mathrm{x}} 725$ (a mutant which overproduces methionine) in norleucine, but valine and leucine increased growth as with wild type (Fig. I $b$ ). However, when the growth experiments were repeated with cysJ538 thy $A$ Nol-r, valine had no stimulatory effect on growth in norleucine while methionine and leucine retained their stimulation (Fig. I c). Thus in this mutant the interference of norleucine with valine metabolism seems to be blocked. This could mean that $c_{5 S} J_{53} 8$ thy $A$ Nol-r lacks a valine uptake system, overproduces valine, or somehow affects the utilization of this amino acid, perhaps by altering the tRNA synthetase.

Knowledge of the genetic map location of the Nol-r mutation could help with interpretation of the nature of the defect it causes, e.g. if it mapped in the ilv (isoleucine/valine) cluster. Preliminary conjugation crosses were carried out using cys 5538 thy A Nol-r as a recipient and HfrB2leu and Hfrk3his as donors with separate selection for cys ${ }^{+}$and thy ${ }^{+}$. $C y s J$ and thy $A$ map at about 90 and 92 min respectively (Sanderson, 1972). With HfrB2leu, whose origin is at about $55 \mathrm{~min}, 95$ to $100 \%$ linkage of Nol-r to both markers was obtained. The HfrK3his origin is at about 93 min and transfer occurs with thy A as a very late marker. With this Hfr strain few thy ${ }^{+}$recombinants were obtained, but $30 \%$ linkage with Nol-r was found whereas linkage between cysJ and Nol-r was low $(7 \%)$. These results suggest that Nol-r lies between cysJ and the HfrK3 origin. This is in agreement with results obtained by transferring $\mathrm{F}^{\prime}$-factors to cysJ538 thy A Nol-r. Two episomes were used: KLFI6 which carries the region of the genome from metC at about 102 min to just beyond thy $A$ but not extending into the cys cluster, and another $\mathrm{F}^{\prime}$-factor carrying the region from about 94 to $90 \mathrm{~min}$, that is including the $c y s$ genes. Each episome was transferred with selection for thy ${ }^{+}$ and in each case the heterogenotes were found to be sensitive to norleucine. Curing of the episome resulted in the simultaneous appearance of norleucine resistance and a thymine requirement. Thus Nol- $r$ is recessive and must map in the region covered by both episomes between the cys cluster and lys $A(94 \mathrm{~min})$. However, when phage grown on $c_{5} J_{53} 8$ thy $A$ Nol-r, or the $c y s^{+}$or $c y s^{+}$thy $y^{+}$derivatives, was used to transduce to prototrophy mutants in the cys cluster and also in $\operatorname{thy} A, \arg B$ and $l y s A$ which are all cotransduced by phage $\mathrm{P}_{22}$, no norleucine-resistant transductants were obtained from at least 300 scored in each cross. Thus the most likely map position for the Nol-r mutation is between the two linkage groups, near $\operatorname{rec} A$ (Sanderson, 1972).

In Escherichia coli, mutants which over-produce valine map in the ilv cluster, in genes concerned with branched-chain amino acid synthetases or in azl (azaleucine resistance), all of which map away from the postulated Nol-r location (Umbarger, I97I ; Taylor \& Trotter, 1972). However, it is possible that the Nol-r mutation is in a different, previously unrecognized valine regulatory gene. Nol-r could possibly reduce incorporation of valine into protein, but 
it maps away from the known tRNA synthetase genes and genes affecting tRNA itself. The other possibility is that cysJ 538 thy $A$ Nol-r is a permease mutant. Two genes involved in uptake of branched-chain amino acids have been mapped in E. coli: brnP and brnQ mapping at about 5 and Io min respectively (Guardiola \& Iaccarino, 1971). CysJ538 thy A Nol-r could be defective in another valine permease or could affect a reaction coupled with valine transport (Kaback, 1972).

I thank Drs M. C. Jones-Mortimer and D. A. Smith for valuable discussions during the course of this study. Mrs J. Dudley and Mrs J. Yeomans gave much appreciated technical support. The work was financed by a Medical Research Council Scholarship for Training in Research Methods.

\section{REFERENCES}

Ayling, P. D. \& Bridgeland, E. S. (1972). Methionine transport in wild-type and transport-defective mutants of Salmonella typhimurium. Journal of General Microbiology 73, 127-14I.

Chater, K. F. \& Rowbury, R. J. (1970). A genetical study of the feedback-sensitive enzyme of methionine synthesis in Salmonella typhimurium. Journal of General Microbiology 63, I I I-1 20.

Cohen, G. N. \& RickenberG, H. V. (1956). Concentration spécifique réversible des amino acides chez Escherichia coli. Annales de l'Institut Pasteur 91, 693-720.

Guardiola, J. \& IACCARINo, M. (197I). Escherichia coli K-I 2 mutants altered in the transport of branchedchain amino acids. Journal of Bacteriology ro8, 1034-1044.

Hobson, A. C. (1973). The biosynthesis of methionine and S-adenosylmethionine and its regulation in Salmonella typhimurium. Ph.D. thesis, University of Birmingham.

Hobson, A. C. \& SMITH, D. A. (1973). S-adenosylmethionine synthetase in methionine regulatory mutants of Salmonella typhimurium. Molecular and General Genetics 126, 7-18.

KABACK, H. R. (1972). Transport across isolated bacterial cytoplasmic membranes. Biochimica et biophysica acta $265,367-416$.

LAWrence, D. A., SMith, D. A. \& Rowbury, R. J. (1968). Regulation of methionine synthesis in Salmonella typhimurium: mutants resistant to inhibition by analogues of methionine. Genetics 58, 473-492.

SANDERSON, K. E. (1972). Linkage map of Salmonella typhimurium, Edition IV. Bacteriological Reviews $3^{6}$, $55^{8}-586$.

SмITH, D. A. (196I). Some aspects of the genetics of methionineless mutants of Salmonella typhimurium. Journal of General Microbiology 24, 335-353.

Smith, H. O. \& Levine, M. (1967). A phage P22 gene controlling integration of prophage. Virology $3^{I}$ 207-216.

TAYlor, A. L. \& Trotter, C. D. (1972). Linkage map of Escherichia coli strain K-I2. Bacteriological Reviews 36, 504-524.

Trupin, J., Dickerman, H., Nirenberg, M. \& Weissbach, H. (1966). Formylation of amino acid analogues of methionine s-RNA. Biochemical and Biophysical Research Communications 24, 50-55.

UMBARGER, H. E. (197I). Metabolite analogues as genetic and biochemical probes. Advances in Genetics I6, II9-I4I.

Whitehouse, J. M. \& SMITH, D. A. (1973). Methionine and vitamin B $_{12}$ repression and precurser induction in the regulation of homocysteine methylation in Salmonella typhimurium. Molecular and General Genetics 120, 341-353. 